Provided for non-commercial research and education use. Not for reproduction, distribution or commercial use.

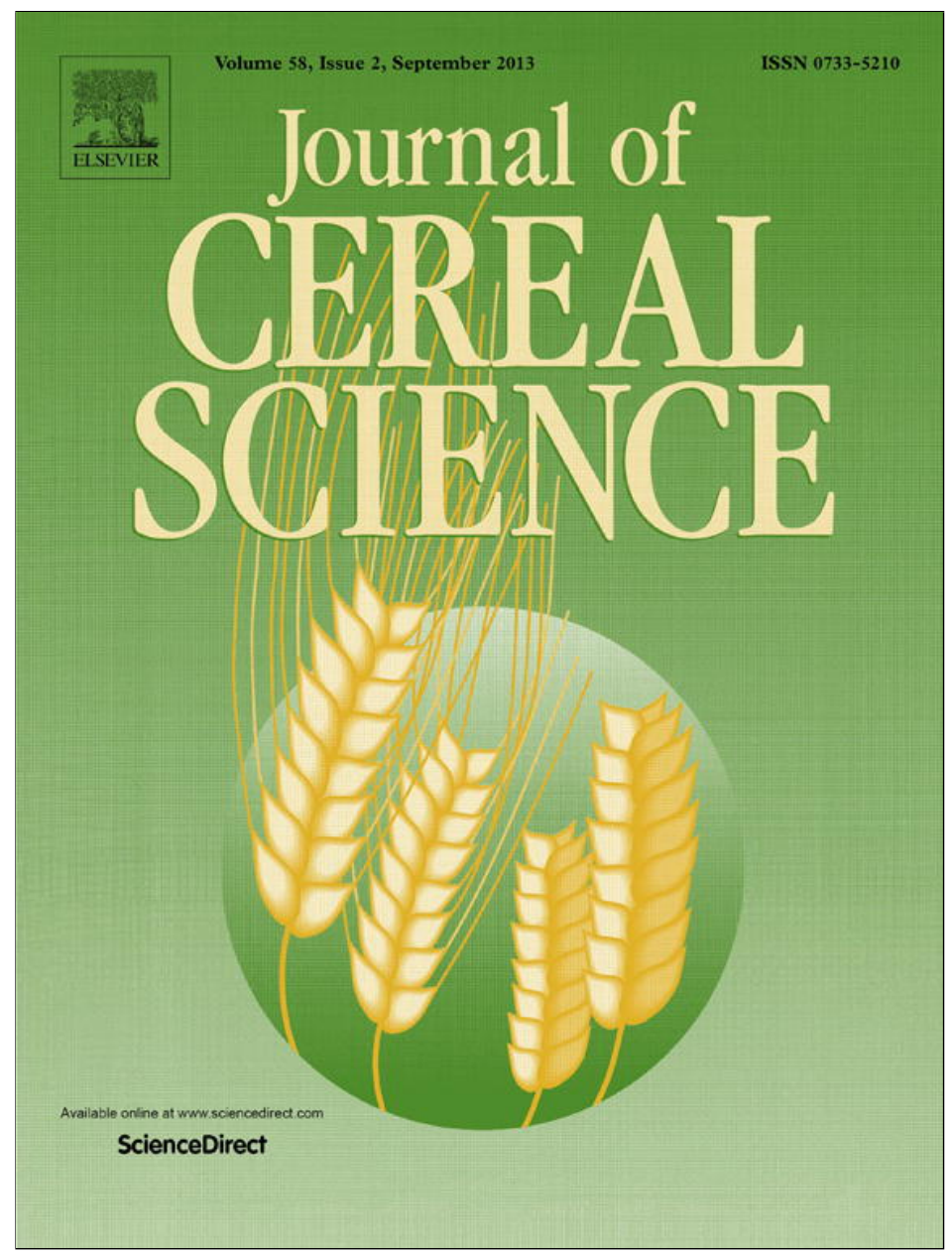

This article appeared in a journal published by Elsevier. The attached copy is furnished to the author for internal non-commercial research and education use, including for instruction at the authors institution and sharing with colleagues.

Other uses, including reproduction and distribution, or selling or licensing copies, or posting to personal, institutional or third party websites are prohibited.

In most cases authors are permitted to post their version of the article (e.g. in Word or Tex form) to their personal website or institutional repository. Authors requiring further information regarding Elsevier's archiving and manuscript policies are encouraged to visit:

http://www.elsevier.com/authorsrights 


\title{
Chemical composition of lipids in brewer's spent grain: A promising source of valuable phytochemicals
}

\author{
José C. del Río*, Pepijn Prinsen, Ana Gutiérrez \\ Instituto de Recursos Naturales y Agrobiología de Sevilla, CSIC, P.O. Box 1052, E- 41080 Seville, Spain
}

\section{A R T I C L E I N F O}

\section{Article history:}

Received 1 April 2013

Received in revised form

1 July 2013

Accepted 3 July 2013

\section{Keywords:}

Brewer's spent grain

Triglycerides

Sterols

Alkylresorcinols

\begin{abstract}
A B S T R A C T
Brewer's spent grain (BSG) is an important by-product from the brewing process produced in high amounts worldwide. BSG is rich in carbohydrates, lignin, proteins and lipids. In this work, the chemical composition of the lipids in BSG was studied in detail by gas chromatography and mass spectrometry. The predominant lipids were triglycerides ( $67 \%$ of total extract), followed by a series of free fatty acids (18\%). Lower amounts of monoglycerides (1.6\%) and diglycerides (7.7\%) were also identified among the lipids in BSG, together with minor amounts of other aliphatic series such as $n$-alkanes and alkylresorcinols. Steroid compounds (steroid hydrocarbons, steroid ketones, free sterols, sterol esters and sterol glycosides) were also found in important amounts in BSG (ca. 5\%), with free and conjugated sterols being the most abundant steroids. BSG can thus be regarded as a valuable source of phytochemicals of interest for the pharmaceutical, cosmetic, food or other industries.
\end{abstract}

(c) 2013 Elsevier Ltd. All rights reserved.

\section{Introduction}

Brewer's spent grain (BSG) is the solid residue obtained from barley (Hordeum vulgare L.) after mashing and filtration from the brewing process. BSG basically consists of the husk-pericarp-seed coat layers that covered the original barley grain (Mussatto et al., 2006). BSG represents up to $30 \%(\mathrm{w} / \mathrm{w}$ ) of the starting malted grain, which makes this a readily available, high volume and low cost byproduct within the brewing industry, and a potentially valuable resource for industrial exploitation. BSG is produced in high amounts from brewing companies worldwide, with an annual production of 30 million tons, among which about 3.4 million tons are produced in Europe each year (Niemi et al., 2012; Stojceska et al., 2008).

BSG is a lignocellulosic material containing cellulose (17-25\%), non-cellulosic carbohydrates (25-35\%), protein (15-24\%) and lignin (8-28\%), with lower amounts of lipids (10\%) and ash (5\%) (Mussatto et al., 2006; Robertson et al., 2010; Santos et al., 2003). The main application of BSG has been basically limited to animal feeding due to its high content of protein and fiber or simply as a landfill. For this reason, the development of new techniques for a more appropriate use of this agro-industrial by-product is of great interest since BSG is produced in large quantities throughout the year. One of the main areas of exploitation of this type of residue would be the recovery of valuable constituents. BSG contains

\footnotetext{
* Corresponding author. Tel.: +3495 4624711; fax: +34 954624002 .

E-mail address: delrio@irnase.csic.es (J.C. del Río).
}

several potentially valuable components suitable for utilization as raw materials for production of added-value products. Lipids in particular, which are a major part of BSG composition, are of considerable interest since they have a wide range of industrial applications in pharmaceutical, food, cosmetics, personal care products, polishes and coatings as well as in other industrial sectors, including the production of liquid biofuels. Lipids were once the primary sources of aliphatic compounds used by the industry, but with the arrival of petroleum, their consumption declined in most industrial applications. Today, market forces, regulations, and concerns about declining of energy resources and the need to mitigate green-house gas emissions and decrease our dependency on fossil fuel reserves bring lipid materials once again to the front, as an alternative to petroleum-derived chemicals and fuels (Octave and Thomas, 2009; Singh Nigam and Singh, 2011). Greater utilization of natural, renewable resources of lipids is vital for an economically viable and environmentally sound society. Therefore, new and alternative sources of biobased lipids need to be investigated. The high amounts of lipids in BSG make this material an interesting feedstock for the production of high value-added lipids in the context of the so-called lignocellulose biorefinery.

For an appropriate evaluation of BSG as a source for added-value products, the complete characterization of the different components present is of high interest. Previous studies have mostly dealt with the composition of carbohydrates, proteins and $p$-hydroxycinnamic acids (Faulds et al., 2002; Mussatto et al., 2007; Robertson et al., 2010). In comparison, studies concerning the composition of lipids in BSG have been relatively scarce and limited 
(Niemi et al., 2012). According to a previous work, BSG contained $11 \%$ lipids, which consisted mostly of triglycerides, with important amounts of free fatty acids. In that work, a gross lipid class profiling was made by TLC, while a more detailed lipid analysis was performed by pyrolysis-gas chromatography-mass spectrometry (PyGC/MS) in the presence of tetramethylammonium hydroxide (TMAH) as a methylating agent, and indicated the predominance of palmitic, oleic and linoleic acids (Niemi et al., 2012). However, this technique is not adequate for detailed lipid analysis since it produces transesterification (and subsequent methylation of the carboxyl and hydroxyl groups) of both free and bound fatty acids in the material, including non-solvent extractable lipids that may be bound in the matrix to structures such as cutin (del Río et al., 1996; del Río and Hatcher, 1998), which makes it impossible to distinguish the origin of the released fatty acids. In addition, this analytical technique prevented the analysis of intact high molecular weight lipids such as sterol esters, sterol glycosides or triglycerides that cannot be discerned and characterized.

In the present work, we have performed a detailed and comprehensive characterization of the lipids present in BSG. The lipid composition was carried out by gas chromatography (GC) and gas chromatography-mass spectrometry (GC-MS) using shortand medium-length high temperature capillary columns, respectively, with thin films, which enables the elution and analysis of a wide range of compounds from fatty acids to intact high molecular weight lipids such as sterol esters, sterol glycosides or triglycerides (Gutiérrez et al., 1998). The knowledge of the precise composition of the lipids in BSG will help to maximize the exploitation of this important agro-industrial lignocellulosic waste product.

\section{Materials and methods}

\subsection{Samples}

Brewers' spent grain was obtained from Adnams brewery (Southwold, UK) and was kindly provided by Prof. Craig B. Faulds (INRA, Marseille). The sample was the residue resulting from wort prepared from malted barley for ale production. Additional information regarding the bulk composition of this sample can be found in Faulds et al. (2008). BSG was lyophilized and milled using a knife mill (Janke and Kunkel, Analysenmühle). Around 500 mg of BSG were subsequently extracted with acetone in a Soxhlet apparatus for $8 \mathrm{~h}$. The acetone extracts were evaporated to dryness, and resuspended in chloroform for chromatographic analysis of the lipids. The acetone-extracted sample was then extracted with hot water $\left(100 \mathrm{~mL}, 3 \mathrm{~h}\right.$ at $\left.100{ }^{\circ} \mathrm{C}\right)$ to determine the water soluble material. Klason lignin content was estimated as the residue after sulfuric acid hydrolysis of the pre-extracted material, corrected for ash and protein content, according to the TAPPI method T222 om88 (Tappi, 2004). The acid-soluble lignin was determined, after the insoluble lignin was filtered off (Duran filter crucible 4; nominal pore size max. 10-16 $\mu \mathrm{m}$ ), by UV-spectroscopic determination at $205 \mathrm{~nm}$ wavelength using $110 \mathrm{~L} \mathrm{~cm}^{-1} \mathrm{~g}^{-1}$ as the extinction coefficient. Holocellulose was isolated from the pre-extracted fibers by delignification for $4 \mathrm{~h}$ using the acid chlorite method (Browning, 1967). The $\alpha$-cellulose content was determined by removing the hemicelluloses from the holocellulose by alkali extraction (Browning, 1967). Ash content was estimated as the residue after $6 \mathrm{~h}$ of heating at $575^{\circ} \mathrm{C}$ according to the TAPPI method T211 om-02 (Tappi, 2004). Three replicates were used for each sample.

\subsection{GC and GC-MS analyses}

An HP 5890 gas chromatograph (Hewlett Packard, Hoofddorp, Netherlands) equipped with a split-splitless injector and a flame ionization detector (FID) was used for GC analyses. The injector and the detector temperatures were set at $300{ }^{\circ} \mathrm{C}$ and $350{ }^{\circ} \mathrm{C}$ respectively. Samples were injected in the splitless mode. Helium was used as the carrier gas. The capillary column used was a high temperature, polyimide coated fused silica tubing DB5-HT ( $5 \mathrm{~m} \times 0.25 \mathrm{~mm}$ I.D., $0.1 \mu \mathrm{m}$ film thickness; J\&W Scientific). The oven was temperature-programmed from $100^{\circ} \mathrm{C}(1 \mathrm{~min})$ to $350^{\circ} \mathrm{C}$ ( $3 \mathrm{~min}$ ) at $15^{\circ} \mathrm{C} \mathrm{min}^{-1}$. Peaks were quantified by area, and a mixture of standards (octadecane, palmitic acid, sitosterol, cholesteryl oleate, sitosteryl $3 \beta$-D-glucopyranoside, and triheptadecanoin) with a concentration range between 0.1 and $1 \mathrm{mg} / \mathrm{mL}$, was used to prepare calibration curves. The correlation coefficient was higher than 0.99 in all the cases. The data from the three replicates were averaged. In all cases, the standard deviations from replicates were below $10 \%$ of the mean values. The total amounts of the different lipid classes were determined by adding up the amounts of their constituent compounds.

The GC-MS analysis was performed on a Varian Star 3400 gas chromatograph (Varian, Walnut Creek, CA) coupled with an Iontrap detector (Varian Saturn 4000; Electron Impact at $70 \mathrm{eV}$ ) equipped with a high-temperature capillary column (DB-5HT, $15 \mathrm{~m} \times 0.25 \mathrm{~mm}$ i.d., $0.1 \mu \mathrm{m}$ film thickness; J\&W Scientific). The MS was run in scan mode $(\mathrm{m} / z$ 50-1000) with the Ion-trap temperature set at $200{ }^{\circ} \mathrm{C}$. Helium was used as carrier gas at a rate of $2 \mathrm{~mL} \mathrm{~min}{ }^{-1}$. The oven was heated from $120^{\circ} \mathrm{C}(1 \mathrm{~min})$ to $380^{\circ} \mathrm{C}$ ( $5 \mathrm{~min}$ ) at $10^{\circ} \mathrm{C} \mathrm{min}^{-1}$. The temperature of the injector during the injection was $120^{\circ} \mathrm{C}$, and $0.1 \mathrm{~min}$ after injection was programmed to $380^{\circ} \mathrm{C}$ at a heating rate of $200^{\circ} \mathrm{C} \mathrm{min}^{-1}$ and held for $10 \mathrm{~min}$. The temperature of the transfer line was set at $300{ }^{\circ} \mathrm{C}$. Bis(trimethylsilyl)trifluoroacetamide (BSTFA) silylation was used to prepare the trimethylsilyl ether derivatives before the analysis. Compounds were identified by comparing their retention times and mass spectra with authentic standards, except for alkylresorcinols, which were only tentatively identified by comparing their mass spectra with those reported in the literature.

\section{Results and discussion}

\subsection{Chemical composition of lipids in BSG}

The abundance of the main constituents of BSG (water-soluble material, lipids, Klason lignin, acid soluble lignin, polysaccharides, proteins, and ash) is shown in Table 1. The data from previous papers regarding this sample are shown for comparison (Faulds et al., 2008; Robertson et al., 2010). The lipids of BSG accounted for $9.2 \%$ of dry material, a value higher than that reported in Faulds et al. (2008) for the same sample but similar to the value previously reported in other papers (Mussatto et al., 2006; Niemi et al., 2012).

Table 1

Abundance of the Main Constituents (\% Dry-Weight) of the Brewers' Spent Grain Sample Selected for this Study. Data from Other Papers (Faulds et al., 2008; Robertson et al., 2010) Regarding the Same Sample Are Shown for Comparison.

\begin{tabular}{lcll}
\hline Constituent & Content $^{\text {a }}$ & $\begin{array}{l}\text { Robertson } \\
\text { et al., 2010 }\end{array}$ & $\begin{array}{l}\text { Faulds } \\
\text { et al., 2008 }\end{array}$ \\
\hline Water-soluble material & $8.3 \pm 1.0$ & n.d. & n.d. \\
Lipids & $9.2 \pm 0.2$ & n.d. & 5.4 \\
Klason lignin & $8.8 \pm 0.9^{\mathrm{b}}$ & 16.0 & 20.1 \\
Acid-soluble lignin & $4.9 \pm 0.3$ & n.d. & n.d. \\
Polysaccharides & $49.4 \pm 2.0$ & 43.3 & 51.0 \\
Proteins & $14.5 \pm 1.0^{\mathrm{c}}$ & 18.8 & 17.6 \\
Ash & $4.9 \pm 0.1$ & n.d. & n.d. \\
\hline
\end{tabular}

a Average of three replicates.

b Corrected for proteins and ash.

c Determined indirectly by subtracting the other components to $100 \%$. 
For a detailed characterization of the lipid composition, the lipid extracts were silylated with BSTFA and the TMS-ether derivatives were analyzed by GC and GC-MS using short- and medium-length high temperature capillary columns, according to the method previously described (Gutiérrez et al., 1998). These chromatographic conditions allow the elution and analysis of a wide range of compounds, from free fatty acids to intact high molecular weight lipids such as sterol esters, sterol glycosides or triglycerides. The GC-MS chromatogram of the TMS-ether derivatives of the extracts from BSG is shown in Fig. 1. The identities and abundances of the main lipophilic compounds identified are detailed in Table 1. The structures of the main lipids present in BSG are depicted in Figs. 2 and 3.

The predominant lipids identified in BSG were triglycerides that accounted for $67 \%$ of all identified compounds, followed by a series of free fatty acids that amounted up to $18 \%$. This data roughly agrees with previously published work that also found a predominance of triglycerides (55\%) and fatty acids (30\%) in BSG (Niemi et al., 2012). In addition, lower amounts of monoglycerides (1.7\%) and diglycerides (7.7\%) were also identified among the lipids in BSG, although only diglycerides could be detected in previous works (Niemi et al., 2012).

However, significant differences were observed with the composition of lipids in BSG reported in previous papers, and many other compounds, not previously reported among the lipids of BSG, have been identified here for the first time. Among these, we report here the occurrence in BSG of steroid compounds (hydrocarbons, ketones, free sterols, sterol esters and sterol glycosides), which are present in important amounts (ca. $5 \%$ of all identified lipids), as well as the occurrence of minor amounts of other compounds, such as series $n$-alkanes and alkylresorcinols.

\subsubsection{Aliphatic series}

Important amounts of glycerides (mono-, di- and triglycerides), were found among the lipids in BSG, triglycerides being the predominant compounds. Triglycerides were identified in high amounts among the lipids in BSG, accounting for $25,300 \mathrm{mg} / \mathrm{kg}$. Previous papers also reported the presence of high amounts of triglycerides in BSG, although they did not detail the composition of the individual compounds (Niemi et al., 2012). In this work, the identification of individual triglycerides was achieved by GC-MS, and the list of triglycerides found in BSG is presented in Table 2. The most abundant triglycerides identified were trilinolein (I), dilinoleoyl palmitin and dilinoleoyl olein. Linoleic acid was the most important fatty acid occurring as triglycerides. Diglycerides, on the other hand, were also found in important amounts $(2880 \mathrm{mg} / \mathrm{kg})$ in BSG, as already reported in a previous paper (Niemi et al., 2012); however, the identification of individual compounds was not reported there because they were only detected by thin-layer chromatography (TLC). In this work, the identification of individual diglycerides was achieved by GC-MS, and the list of identified compounds is shown in Table 2 . The most abundant diglycerides found were 1,2- and 1,3-palmitoyllinolein, and 1,2-dilinolein (II) and 1,3-dilinolein (III), with a predominance of the 1,3-isomers. As occurred with triglycerides, linoleic acid was the most important fatty acid present as diglycerides. The series of monoglycerides accounted for $610 \mathrm{mg} / \mathrm{kg}$, and ranged from 2,3-dihydroxypropyl tetradecanoate $\left(C_{14}\right)$ to 2,3-dihydroxypropyl octacosanoate $\left(C_{28}\right)$, with a strong even-over-odd carbon atom number predominance, and with 2,3-dihydroxypropyl octadecadienoate (1-monolinolein, IV) being the most abundant. The saturated monoglyceride 1monopalmitin was also present in important amounts. Monoglycerides were not identified in previous papers (Niemi et al., 2012).

Free fatty acids were the second most abundant class of lipids identified in BSG, accounting for $6710 \mathrm{mg} / \mathrm{kg}$. The series ranges from tetradecanoic acid $\left(C_{14}\right)$ to triacontanoic acid $\left(C_{30}\right)$, with a strong even-over-odd carbon atom number predominance. The most abundant free fatty acids were hexadecanoic (palmitic) acid $(\mathbf{V})$, and the unsaturated cis-9-octadecenoic (oleic, VI), and cis,cis9,12-octadecadienoic (linoleic, VII) acids. Previous works also indicated that the most abundant fatty acids in BSG were linoleic, palmitic and oleic acids, with small amounts of other fatty acids such as stearic acid (Niemi et al., 2012). However, a direct comparison with previous data cannot be made since they were obtained upon Py-GC/MS in the presence of TMAH, which releases (as their methyl ester derivatives) both the free and the esterified fatty acids present in BSG. Therefore, the composition of fatty acids reported in that paper corresponded not only to free fatty acids but also included fatty acids occurring as mono-, di- and triglycerides and as sterol esters, which are major components of BSG lipids.

Finally, minor amounts of $n$-alkanes $(80 \mathrm{mg} / \mathrm{kg}$ ) could also be identified among the lipids in BSG, ranging from $n$-tricosane $\left(\mathrm{C}_{23}\right)$ to $n$-hentriacontane $\left(C_{31}\right)$, with the occurrence of only the odd atom

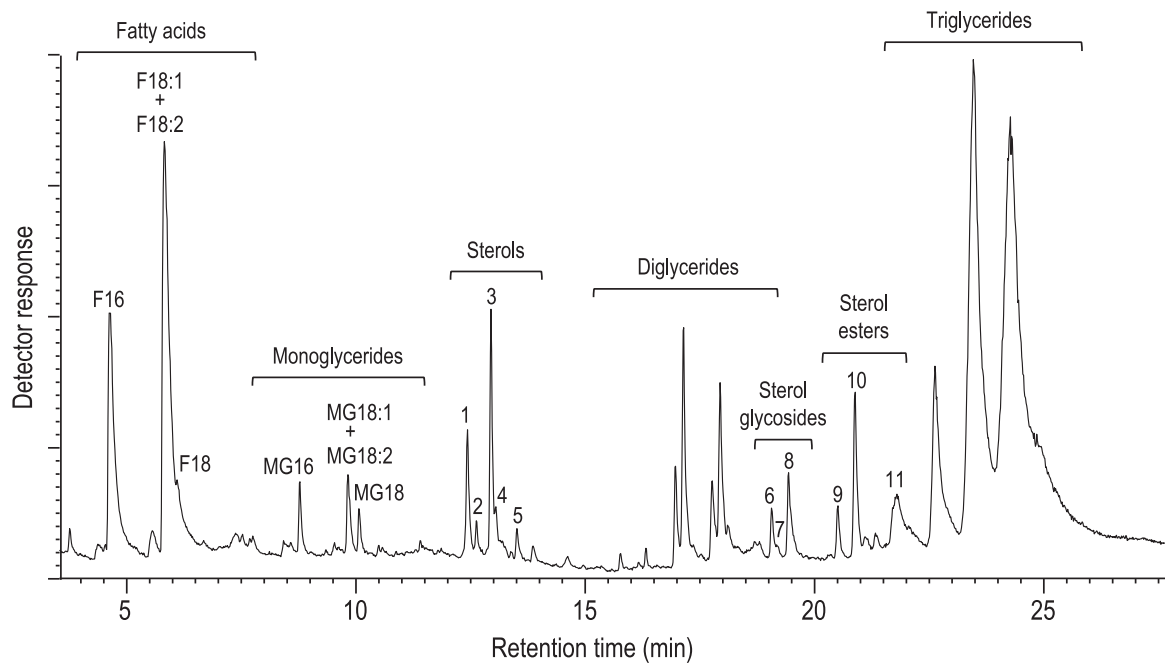

Fig. 1. GC-MS chromatogram (Total Ion Chromatogram) of the lipid extracts from BSG, as TMS-ether derivatives. F( $n$ ): $n$-fatty acids; MG(n): monoglycerides; $n$ denotes the total carbon atom number. Other compounds reflected are: (1) campesterol; (2) stigmasterol; (3) sitosterol; (4) $\Delta 5$-avenasterol; (5) 24-methylenecycloartanol; (6) campesteryl 3ß-D-

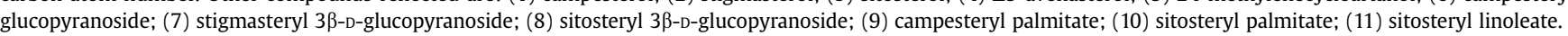




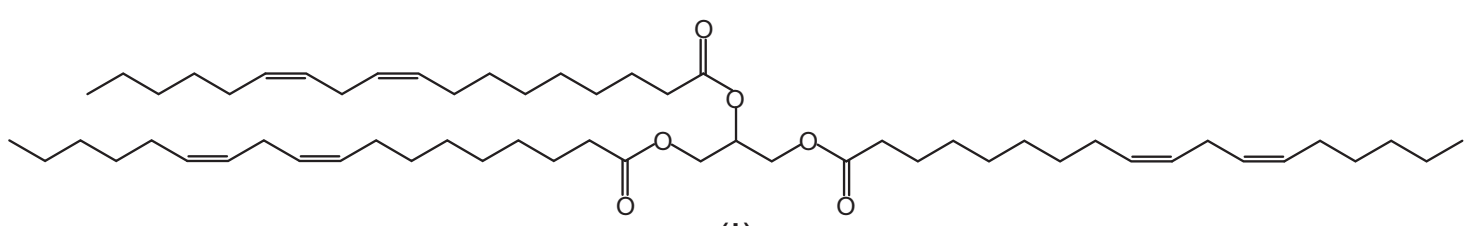

(I)<smiles>CCCCCC=CCCCCCCCCCC(=O)OC(CO)COC(=O)CCCCCCCC=CCCCCCCCC</smiles>

(II)<smiles>CCCCCCC=CCC=CCCCCCCCC(=O)OCC(O)COC(=O)CCCCCCCCCCCCCCCCC</smiles>

(III)<smiles>CCCCCC=CCC=CCCCCCCCC(=O)OCC(O)CO</smiles><smiles>CCCCCCCCC=CCCCCCCCC(=O)O</smiles>

(VI)<smiles>CCCCCCC=CCC=CCCCCCCCC(=O)O</smiles>

(VII)

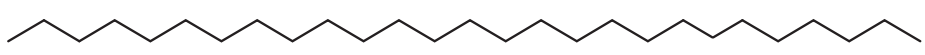

(VIII)<smiles>CCCCCCCCCCCCCCCCCCCCc1cc(O)cc(O)c1</smiles>

Fig. 2. Structures representative of the main aliphatic lipophilic compounds identified in BSG and referred in the text. (I) trilinolein; (II) 1,2-dilinolein; (III) 1,3-dilinolein; (IV) 1monolinolein; (V) hexadecanoic (palmitic) acid; (VI) cis-9-octadecenoic (oleic) acid; (VII) cis,cis-9,12-octadecadienoic (linoleic) acid; (VIII) n-heptacosane; (IX) 1,3-dihydroxy-5-nheneicosylbenzene.

carbon number homologs and heptacosane (VIII) being the predominant homolog in the series, followed by nonacosane.

\subsubsection{Alkylresorcinols}

A series of 5- $n$-alkylresorcinos could also be detected among the lipids of BSG, although in low amounts ( $30 \mathrm{mg} / \mathrm{kg}$ ). The identification of 5- $n$-alkylresorcinols was obtained from their mass spectra that show a characteristic base peak ion at $m / z 268$, typical of these molecules (Zarnowski et al., 2002). A representative mass spectrum of a 5- $n$-alkylresorcinol is shown in Fig. 4. The series of 5- $n$-alkylresorcinols was found in BSG ranging from 5-nonadecyl $\left(\mathrm{C}_{19}\right)$ to 5 heptacosylresorcinol $\left(C_{27}\right)$, with the exclusive occurrence of the odd carbon atom-numbered homologs, and 5-heneicosylresorcinol $\left(\mathrm{C}_{21}, \mathbf{I X}\right)$ being the most abundant one. Alkylresorcinols are known to occur in cereal grains, including barley, where 5-heneicosylresorcinol is the major alkylresorcinol present (Zarnowski et al., 2002).

\subsubsection{Steroid compounds}

Different classes of steroid compounds, namely steroid hydrocarbons, steroid ketones, free sterols, sterol glycosides and sterol esters, could be identified among the lipids in BSG, and their occurrence is reported here for the first time. Free sterols were the most abundant steroid compounds, accounting for $910 \mathrm{mg} / \mathrm{kg}$. 
<smiles>[X]C1=CCC2C(CCC3(C)C(C(C)CCC(CC)C(C)C)CCC23)C12CCC(O)CC2</smiles><smiles>[Y]C1=CCC2C(CCC3(C)C(C(C)CCC(C)C(C)C)CCC23)C12CCC(O)CC2</smiles><smiles>CCC(/C=C/C(C)C1CCC2C3CC=C4CC(O)CCC4(C)C3CCC12C)C(C)C</smiles><smiles>C/C=C(/CCC(C)C1CCC2C3CC=C4CC(O)CCC4(C)C3CCC12C)C(C)C</smiles>

(XIII)<smiles>CCC(CCC(C)C1CCC2C3=CCC4CC(O)CCC4(C)C3CCC21C)C(C)C</smiles>

(XIV)<smiles>CC(C)C(C)CCC(C)C1CCC2C3CCC4CC(O)CCC4(C)C3CCC12C</smiles>

$(\mathrm{XVI})$<smiles>CCC(CCC(C)C1CCC2C3CCC4CC(O)CCC4(C)C3CCC12C)C(C)C</smiles>

(XVII)<smiles>C/C=C(/CCC(C)C1CCC2C3=CCC4CC(O)CCC4(C)C3CCC21C)C(C)C</smiles>

(XV)<smiles>C=C(CCC(C)C1CCC2(C)C3CCC4C(C)(C)C(O)CCC45CC35CCC12C)C(C)C</smiles>

(XVIII)<smiles>[X][M]CCCCCCCCCCCCCCCCC(CC)C(C)CCC(C)C1CCC2C3C(=O)C=C4C=CCCC4(C)C3CCC12C</smiles>

(XXI)<smiles>CCC(CCC(C)C1CCC2C3CCC4=CC(=O)CCC4(C)C3CCC12C)C(C)C</smiles>

(XXII)<smiles>CCC(C)C(C)CCC(C)C(C)CCCC(C)C(CC)CCC(CC)C(C)C</smiles><smiles>CCC(CCC(C)C1CCC2C3CC=C4CC(OC5OC(C)C(O)O5)CCC4(C)C3CCC12C)C(C)C</smiles>

\footnotetext{
(XX)
}<smiles>CCC(CCC(C)C1CCC2C3CC=C4C=CCCC4(C)C3CCC12C)C(C)C</smiles>

(XXIII)

Fig. 3. Structures of the main steroid compounds identified in BSG and referred in the text. (X) sitosterol; (XI) campesterol; (XII) stigmasterol; (XIII) $\Delta 5$-avenasterol; (XIV) $\Delta 7$ stigmastenol; (XV) $\Delta$ 7-avenasterol; (XVI) campestanol; (XVII) sitostanol; (XVIII) 24-methylenecycloartanol; (XIX) sitosteryl palmitate; (XX) sitosteryl 3 $\beta$-D-glucopyranoside; (XXI) stigmasta-3,5-dien-7-one; (XXII) stigmast-4-en-3-one; (XXIII) stigmasta-3,5-diene.

Sitosterol (X) was the most important free sterol in BSG, followed by campesterol $(\mathbf{X I})$. In addition, lower amounts of other sterols, including stigmasterol (XII), $\Delta 5$-avenasterol (XIII), $\Delta 7$-stigmastenol (XIV), $\Delta 7$-avenasterol (XV) and the saturated campestanol (XVI) and sitostanol (XVII), were also identified in BSG. All these sterols are known to occur in barley grains (Lampi et al., 2004; Dutta and Appelqvist, 1996). Additionally, important amounts of 24methylenecycloartanol (XVIII) also occurred in BSG. Sterol esters were also found in important amounts in BSG $(550 \mathrm{mg} / \mathrm{kg})$. The sterol ester series corresponded to campesterol, stigmasterol, and sitosterol esterified with different fatty acids. All the esterified sterol ester series showed two major peaks for the $C_{16}$ (palmitic acid) and $\mathrm{C}_{18}$ fatty acids, including stearic acid and the unsaturated oleic and linoleic acids, with sitosteryl palmitate (XIX) as the most predominant sterol ester. Sterol glycosides were also identified among the lipophilic extracts of BSG in important amounts (390 $\mathrm{mg} / \mathrm{kg}$ ). Sitosteryl 3 $\beta$-D-glucopyranoside (XX) was the most predominant with lower amounts of campesteryl and stigmasteryl $3 \beta$-D-glucopyranosides. The identification of sterol glycosides was accomplished (after BSTFA derivatization of the lipid extract) by comparison with the mass spectra and relative retention times of authentic standards (Gutiérrez and del Río, 2001). Despite their 
Table 2

Composition and Abundance (mg/kg; Dry, Ash-free Basis) of Main Lipids Identified in the Extracts of BSG.

\begin{tabular}{|c|c|}
\hline Compound & Abundance \\
\hline$n$-Fatty Acids & 6710 \\
\hline$n$-Tetradecanoic acid & 15 \\
\hline n-Pentadecanoic acid & 10 \\
\hline n-Hexadecanoic acid & 2180 \\
\hline$n$-Heptadecanoic acid & 25 \\
\hline cis,cis-Octadeca-9,12-dienoic acid & 3130 \\
\hline cis-Octadec-9-enoic acid & 610 \\
\hline n-Octadecanoic acid & 615 \\
\hline$n$-Nonadecanoic acid & 3 \\
\hline$n$-Eicosanoic acid & 30 \\
\hline n-Heneicosanoic acid & 5 \\
\hline n-Docosanoic acid & 25 \\
\hline$n$-Tricosanoic acid & 7 \\
\hline$n$-Tetracosanoic acid & 32 \\
\hline n-Pentacosanoic acid & 5 \\
\hline n-Hexacosanoic acid & 8 \\
\hline n-Heptacosanoic acid & 2 \\
\hline n-Octacosanoic acid & 3 \\
\hline$n$-Nonacosanoic acid & 1 \\
\hline$n$-Triacontanoic acid & 4 \\
\hline n-Alkanes & 80 \\
\hline$n$-Tricosane & 5 \\
\hline$n$-Pentacosane & 10 \\
\hline$n$-Heptacosane & 25 \\
\hline n-Nonacosane & 22 \\
\hline$n$-Hentriacontane & 18 \\
\hline 5-n-Alkylresorcinols & 30 \\
\hline 1,3-Dihydroxy-5-n-nonadecylbenzene & 4 \\
\hline 1,3-Dihydroxy-5- $n$-heneicosylbenzene & 15 \\
\hline 1,3-Dihydroxy-5- $n$-tricosylbenzene & 5 \\
\hline 1,3-Dihydroxy-5-n-pentacosylbenzene & 5 \\
\hline 1,3-Dihydroxy-5- $n$-heptacosylbenzene & 1 \\
\hline Steroid hydrocarbons & 30 \\
\hline Stigmasta-3,5,7-triene & 10 \\
\hline Stigmasta-3,5-diene & 20 \\
\hline Sterols & 910 \\
\hline Campesterol & 250 \\
\hline Campestanol (= ergostanol) & 20 \\
\hline Stigmasterol & 50 \\
\hline Sitosterol & 450 \\
\hline Sitostanol (= stigmastanol) & 6 \\
\hline$\Delta 5$-Avenasterol & 60 \\
\hline$\Delta 7$-Stigmastenol & 20 \\
\hline$\Delta 7$-Avenasterol & 14 \\
\hline 24-Methylenecycloartenol & 40 \\
\hline Steroid ketones & 25 \\
\hline Stigmasta-3,5-dien-7-one & 7 \\
\hline Stigmast-4-en-3-one & 18 \\
\hline Monoglycerides & 610 \\
\hline 2,3-Dihydroxypropyl tetradecanoate & 5 \\
\hline 2,3-Dihydroxypropyl hexadecanoate & 200 \\
\hline 2,3-Dihydroxypropyl octadecadienoate & 190 \\
\hline 2,3-Dihydroxypropyl octadecenoate & 60 \\
\hline 2,3-Dihydroxypropyl octadecanoate & 120 \\
\hline 2,3-Dihydroxypropyl eicosanoate & 7 \\
\hline 2,3-Dihydroxypropyl docosanoate & 7 \\
\hline 2,3-Dihydroxypropyl tetracosanoate & 10 \\
\hline 2,3-Dihydroxypropyl hexacosanoate & 8 \\
\hline 2,3-Dihydroxypropyl octacosanoate & 3 \\
\hline Diglycerides & 2880 \\
\hline 1,2-Dipalmitin & 20 \\
\hline 1,3-Dipalmitin & 60 \\
\hline 1,2-Palmitoyllinolein & 235 \\
\hline 1,2-Palmitoylolein & 100 \\
\hline 1,2-Palmitoylstearin & 50 \\
\hline 1,3 -Palmitoyllinolein & 670 \\
\hline 1,3-Palmitoylolein & 200 \\
\hline 1,3-Palmitoylstearin & 142 \\
\hline 1,2-Dilinolein & 184 \\
\hline 1,2-Linoleoylolein & 120 \\
\hline
\end{tabular}

Table 2 (continued)

\begin{tabular}{lr}
\hline Compound & Abundance \\
\hline 1,2-Linoleoylstearin + 1,2-diolein & 65 \\
1,2-Oleoylstearin & 7 \\
1,2-Distearin & 57 \\
1,3-Dilinolein & 415 \\
1,3-Linoleoylolein & 222 \\
1,3-Linoleoylstearin + 1,3-diolein & 113 \\
1,3-Oleoylstearin & 40 \\
1,3-Distearin & 180 \\
Sterol glycosides & \\
Campesteryl- $\beta$-D-glucopyranoside & 390 \\
Stigmasteryl- $\beta$-D-glucopyranoside & 110 \\
Sitosteryl- $\beta$-D-glucopyranoside & 27 \\
Sterol esters & 253 \\
Campesteryl hexadecanoate & 550 \\
Stigmasteryl hexadecanoate & 96 \\
Sitosteryl hexadecanoate & 5 \\
Campesteryl octadecadienoate & 330 \\
Stigmasteryl octadecadienoate & 30 \\
Sitosteryl octadecadienoate & 1 \\
Triglycerides & 88 \\
Tripalmitin & 25,300 \\
Dipalmitoyl linolein & 30 \\
Dipalmitoyl olein & 1760 \\
Dilinoleoyl palmitin & 600 \\
Linoleoyloleoyl palmitin & 5510 \\
Linoleoylsteaoryl palmitin + dioleoyl palmitin & 3520 \\
Trilinolein & 130 \\
Dilinoleoyl olein & 5340 \\
Dilinoleoyl stearin + disteaoryl linolein & 5970 \\
Tristearin + linoleoyloleoyl stearin & 2130 \\
\hline & 310 \\
\hline
\end{tabular}

high abundance, free sterols, sterol esters and sterol glycosides were not reported previously among the lipids in BSG (Niemi et al., 2012). Steroid ketones could also be detected among the lipids of BSG although in lower amounts ( $25 \mathrm{mg} / \mathrm{kg}$ ) and consisted mainly of stigmast-3,5-dien-7-one (XXI) and stigmast-4-en-3-one (XXII). Finally, steroid hydrocarbons, including stigmasta-3,5,7-triene and stigmasta-3,5-diene (XXIII), were also found in BSG, albeit in low amounts $(30 \mathrm{mg} / \mathrm{kg})$. The relatively high amounts of steroid compounds present in BSG, particularly free sterols, sterol esters and sterol glycosides, makes BSG a good source of valuable phytosterols.

\subsection{Potential uses of BSG lipids}

From the chemical composition described above, the BSG extract might be seen as an interesting source of fatty acids, triglycerides and phytosterols, considering that these families have a wide range of nutraceutical, pharmaceutical and cosmetic properties and are also of interest for other industrial sectors. For example, phytosterols, as functional ingredients in foods, appear to be a practical and safe option for reducing blood cholesterol levels (Quílez et al., 2003). Also, alkylresorcinols, although found to be minor components in BSG, are important for cancer preventive activity as they exert cytotoxic effects on cancer cells (Liu et al., 2012). On the other hand, linoleic acid belongs to the family of the essential unsaturated omega- 6 fatty acids that humans and other animals must ingest because the body cannot synthesize them from other food components. Moreover, linoleic acid is also used in pharmaceutical and cosmetic products and is considered to influence the metabolic processes in the skin and to promote the activity of vitamins $A$ and $E$ and recovery barrier properties of stratum corneum (Huang et al., 1999). The fact that most vegetable oils and fats are nontoxic allows them to be used as reliable excipients or carriers in many pharmaceutical formulations. Lipids are already used in a wide variety of oral drug delivery applications 


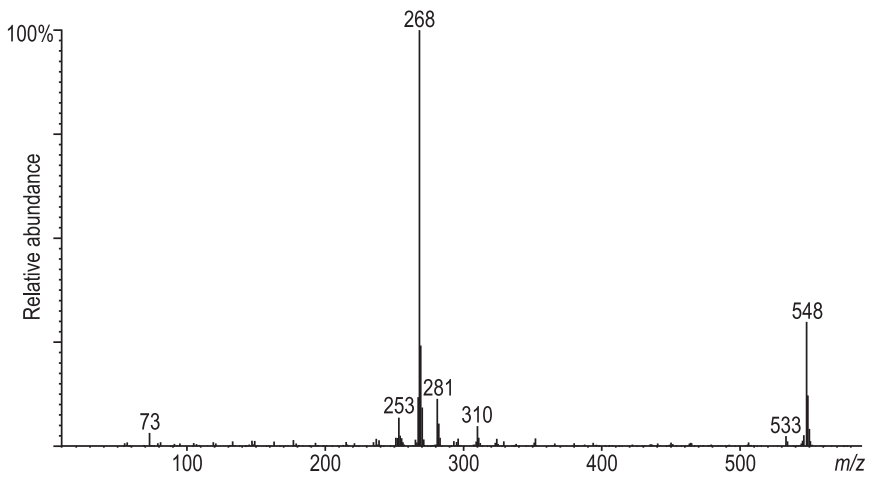

Fig. 4. Mass spectrum of the TMS-ether derivative of a representative 5- $n$-alkylresorcinol (1,3-dihydroxy-5- $n$-heneicosylbenzene).

(Hernández, 2005). Thus, it is known that the addition of fatty acids can improve the bioavailability of drugs that are poorly absorbed by the gastrointestinal tract by increasing their uptake into the lymphatic system (Porter, 1997). Finally, the high content of triglycerides present in BSG would also make this an alternative feedstock for the production of biodiesel, which is currently largely derived from oil seed crops (Singh Nigam and Singh, 2011).

Variations in BSG composition can be expected to arise from differences in barley malting cultivars, malting practices, adjuncts added and wort production during mashing processes in breweries (Robertson et al., 2010). Therefore, additional research should be directed to verify that these results are also valid for other BSG samples.

\section{Conclusions}

The present paper provides for the first time a detailed and comprehensive description of the lipids present in BSG, which is highly valuable information for a more complete industrial utilization of this lignocellulosic material that is regarded as a waste. The results of this study highlight the potential of BSG as a source of valuable compounds, and may assist in the development of strategies for integral exploitation of BSG, reducing the environmental impact of brewing industries. In this sense, and due to the large amounts of BSG produced annually, it can be viewed as a promising source of highly valuable compounds of diverse industrial interest.

\section{Acknowledgments}

We thank Prof. Craig B. Faulds (INRA, Marseille, France) for providing the BSG sample analyzed in this study. This study has been funded by the Spanish project AGL2011-25379, the CSIC project 201040E075 and the EU-project LIGNODECO (KBBE244362). Pepijn Prinsen thanks the Spanish Ministry of Science and Innovation for a FPI fellowship.

\section{References}

Browning, B.L., 1967. Methods of Wood Chemistry, vol. II. Wiley-Interscience Publishers, New York.

del Río, J.C. González-Vila, FJ., Martín, F., 1996. Thermally assisted hydrolysis and alkylation as a novel pyrolytic approach for the structural characterization of natural biopolymers and geomacromolecules. Trends in Analytical Chemistry $15,70-79$.

del Río, J.C., Hatcher, P.G., 1998. Analysis of aliphatic biopolymers using thermochemolysis with tetramethylammonium hydroxide (TMAH) and gas chromatography-mass spectrometry. Organic Geochemistry 29, 1441-1451.

Dutta, P.C., Appelqvist, L.-A., 1996. Saturated sterols (stanols) in unhydrogenated and hydrogenated edible vegetable oils and in cereal lipids. Journal of the Science of Food and Agriculture 71, 383-391.

Faulds, C.B., Sancho, A.I., Bartolomé, B., 2002. Mono- and dimeric ferulic acid release from brewer's spent grain by fungal feruloyl esterase. Applied Microbiology and Biotechnology 60, 489-493.

Faulds, C.B., Robertson, J.A., Waldron, K.W., 2008. Effect of pH on the solubilization of brewers' spent grain by microbial carbohydrases and proteases. Journal of Agricultural and Food Chemistry 56, 7038-7043.

Gutiérrez, A., del Río, J.C., González-Vila, F.J., Martín, F., 1998. Analysis of lipophilic extractives from wood and pitch deposits by solid-phase extraction and gas chromatography. Journal of Chromatography A 823, 449-455.

Gutiérrez, A., del Río, J.C., 2001. Gas chromatography/mass spectrometry demonstration of steryl glycosides in eucalypt wood, kraft pulp and process liquids. Rapid Communications in Mass Spectrometry 15, 2515-2520.

Hernandez, E., 2005. Pharmaceutical and cosmetic use of lipids. In: Shahidi, F (Ed.), Bailey's Industrial Oil and Fat Products. John Wiley \& Sons, New York, pp. 391-411.

Huang, F.C., Ju, Y.H., Chiang, J.C., 1999. Gamma-Linolenic acid-rich triacylglycerols derived from borage oil via Lipase-catalyzed reactions. Journal of the American Oil Chemist's Society 76, 833-837.

Lampi, A.-M., Moreau, R.A., Piironen, V., Hicks, K.B., 2004. Pearling barley and rye to produce phytosterol-rich fractions. Lipids 39, 783-787.

Liu, L., Winter, K.M., Stevenson, L., Morris, C., Leach, D.N., 2012. Wheat bran lipophilic compounds with in vitro anticancer effects. Food Chemistry 130 156-164.

Mussatto, S.I., Dragone, G., Roberto, I.C., 2006. Brewers' spent grain: generation, characteristics and potential applications. Journal of Cereal Science 43, 1-14.

Mussatto, S.I., Dragone, G., Roberto, I.C., 2007. Ferulic and p-coumaric acids extraction by alkaline hydrolysis of brewer's spent grain. Industrial Crops and Products 25, 231-237.

Niemi, P Tamminen, $T$, Smeds, A Viljanen, $K$, Ohra-aho, $T$, HolopainenMantila, U., Faulds, C.B., Poutanen, K., Buchert, J., 2012. Characterization of lipids and lignans in brewer's spent grain and its enzymatically extracted fraction. Journal of Agricultural and Food Chemistry 60, 9910-9917.

Octave, S., Thomas, D., 2009. Biorefinery: towards an industrial metabolism. Biochimie 91, 659-664.

Porter, C.J., 1997. Drug delivery to the lymphatic system. Critical Reviews in Therapeutic Drug Carrier Systems 14, 333-393.

Quílez, J., García-Lorda, P., Salas-Salvadó, J., 2003. Potential uses and benefits of phytosterols in diet: present situation and future directions. Clinical Nutrition 22, 343-351.

Robertson, J.A., I'Anson, K.J.A., Treimo, J., Faulds, C.B., Brocklehurst, T.F., Eijsink, V.G.H., Waldron, K.W., 2010. Profiling brewers' spent grain for composition and microbial ecology at the site of production. LWT-Food Science and Technology 43, 890-896.

Santos, M., Jiménez, J.J., Bartolomé, B., Gómez-Cordovés, C., del Nozal, M.J. 2003. Variability of brewers' spent grain within a brewery. Food Chemistry $80,17-21$.

Singh Nigam, P., Singh, A., 2011. Production of liquid biofuels from renewable resources. Progress in Energy and Combustion Science 37, 52-68.

Stojceska, V., Ainsworth, P., Plunkett, A., Ibanoglu, S., 2008. The recycling of brewer's processing by-product into ready-to-eat snacks using extrusion technology. Journal of Cereal Science 47, 469-479.

Tappi, 2004. Tappi Test Methods 2004-2005. Tappi Press, Norcoss, GA

Zarnowski, R., Suzuki, Y., Yamaguchi, I., 2002. Alkylresorcinols in barley (Hordeum vulgare L. distichon) grains. Zeitschrift für Naturforschung 57c, 57-62. 